\title{
Pendidikan Kesehatan Tentang Personal Hygiene Pada Siswa SMK Al Halim Garut
}

\author{
Udin Rosidin ${ }^{1}$, Nina Sumarni ${ }^{2}$, Iwan Suhendar ${ }^{3}$ \\ 1,2,3Universitas Padjadjaran \\ e-mail: ${ }^{1}$ udin.rosidin@unpad.ac.id, 2n.sumarni@unpad.ac.id, 3iwansuhendar04@gmail.com
}

\begin{abstract}
Abstrak
Upaya hidup sehat harus dijalankan oleh masyarakat sesuai dengan program pemerintah yang mengutamakan upaya promotif dan preventif. Program tersebut memerlukan peran semua sektor dan peran serta seluruh masyarakat. Gerakan ini harus dilaksanakan disemua tatanan termasuk institusi pendidikan. Sekolah Menengah Kejuruan (SMK) Al Halim adalah institusi pendidikan yang mempunyai peranan penting dalam gerakan masyarakat sehat. SMK Al Halim merupakan sekolah yang berbasis pesantren sehingga seluruh siswanya merupakan santri dipondok pesantren. Pada survey awal yang dilakukan kepada siswa-siswi SMK AlHalim menunjukan masalah personal hygiene menjadi salah satu permasalahan yang dikeluhkan oleh siswa yang dimungkinkan karena kurangnya pengetahuan siswa. Berdasarkan permasalahan terebut diatas maka perlu dilakukan kegiatan pengabdian tentang peningkatan pengetahuan siswa dalam pelaksanaan personal hygiene di SMK Al Halim Garut. Tujuan kegiatan ini adalah untuk meningkatkan pemahaman siswa di SMK Al Halim. Metode pelaksanaan melalui dua tahap yaitu tahap persiapan dan tahap pelaksanaan. Tahap persiapan berupa pelaksanaan survey dan persiapan sosial untuk membangun komitmen terhadap pelaksanaan pendidikan kesehatan. Sedangkan tahap pelaksanaan berupa pendidikan kesehatan tentang personal hygiene. Kegiatan ini menunjukkan adanya perbedaan rata-rata nilai pengetahuan sebelum dan sesudah dilaksanakan pendidikan kesehatan. Kesimpulan dari pengabdian masyarakat adalah adanya peningkatan pengetahuan siswa SMK Al Halim tentang personal hygiene.
\end{abstract}

Kata Kunci: Pengetahuan, Personal Hygiene, Pendidikan Kesehatan.

\begin{abstract}
Efforts to live healthy must be carried out by the community in accordance with government programs that prioritize promotive and preventive efforts. The program requires the role of all sectors and the participation of the entire community. This movement must be implemented in all settings, including educational institutions. Al Halim Vocational High School (SMK) is an educational institution that has an important role in the healthy society movement. SMK Al Halim is a pesantren-based school so that all students are students in Islamic boarding schools. In the initial survey conducted on the students of SMK Al Halim, it showed that the problem of personal hygiene was one of the problems that students complained about which was possible due to the lack of student knowledge. Based on the above problems, it is necessary to carry out community service activities regarding increasing student knowledge in the implementation of personal hygiene at SMK Al Halim Garut. The purpose of this activity is to improve students' understanding at SMK Al Halim. The method of implementation consists of two stages, namely
\end{abstract}




\section{JURNAL ABDIMAS BSI}

Jurnal Pengabdian Kepada Masyarakat

the preparation stage and the implementation stage. The preparatory stage is in the form of conducting surveys and social preparation to build commitment to the implementation of health education. While the implementation stage is in the form of health education about personal hygiene. This activity shows that there is a difference in the average value of knowledge before and after the implementation of health education. The conclusion from community service is that there is an increase in the knowledge of SMK Al Halim students about personal hygiene.

Keywords: Knowledge, Personal Hygiene, Health Education.

\section{Pendahuluan}

\section{Latar Belakang Pengabdian}

Masalah kesehatan dirasakan hampir oleh sebagian besar masyarakat. Selain masalah penyakit infeksi yang masih tinggi juga penyakit tidak menular semakin banyak terjadi. Upaya untuk mengatasi permasalahan tersebut kebijakan pemerintah saat ini adalah dengan menggalakan hidup bersih dan sehat. Program tersebut sudah dicanangkan secara nasional dengan sebutan gerakan masyarakat hidup sehat (Irnawati \& Kamalah, 2020). Memperhatikan Instruksi Presiden Republik Indonesia Nomor 1 tahun 2017 tentang Gerakan Masyarakat Hidup Sehat (Germas) menyebutkan bahwa untuk menyukseskan Germas tidak bisa hanya mengandalkan sektor kesehatan saja tetapi diperlukan peran sektor lain dan peran serta seluruh masyarakat. Menurut Instruksi Presiden tersebut setiap lembaga negara harus menetapkan kebijakan dan mengambil langkah-langkah sesuai tugas, fungsi, dan kewenangan masing-masing untuk mewujudkan gerakan masyarakat hidup sehat.

Sekolah Menengah Kejuruan (SMK) Al Halim adalah salah satu institusi pendidikan dengan 381 orang siswa, 175 siswa laki-laki dan 205 siswa perempuan. Pada survey awal yang dilakukan kepada siswa-siswi SMK Al Halim menunjukan masalah personal hygiene menjadi salah satu permasalahan yang dikeluhkan oleh siswa. Personal hygine merupakan cerminan perilaku hidup bersih dan sehat. Pemeliharaan Personal hygiene diperlukan agar individu merasa nyaman, aman dan sehat, kebiasaan melakukan personal hygiene merupakan perilaku kesehatan (Sulistyowati \& Handayani, 2012). Menurut WHO di beberapa negara berkembang prevalensinya akibat personal hygiene dilaporkan 6\%-27\%, sedangkan di Indonesia telah terdaftar pada tahun 2010 sebesar 4,60 \%. Di Indonesia kasus personal hygiene menempati urutan ke-2 (Juliansyah \& Minartami, 2017). Sedangkan di Kabupaten Garut kegiatan personal hygiene yaitu menggosok gigi memiliki tingkat persentase yang rendah yaitu, 9\% dan perilaku benar mencuci tangan 26,8\% (Dinas Kesehatan Kabupaten Garut, 2017).

Rendahnya pelaksanaan personal hygiene tersebut diperburuk dengan rendahnya pelaksanaan setiap indikator hidup bersih dan sehat. Riset Kesehatan Dasar (Riskesdas) tahun 2007 menunjukkan bahwa masyarakat masih memiliiki kebiasaan hdup bersih dan sehat yang rendah. Dalam penelitian (Proverawati \& Rahmawati, 2012) hanya 31,6 \% responden setelah BAB/BAK selalu melakukan cuci tangan dan 
kafang kadang $63,2 \%$ responden. Sebesar $52,6 \%$ selalu mengganti baju setiap hari dan $47,4 \%$ kadang-kadang.

SMK Al Halim merupakan sekolah yang berbasis pesantren sehingga seluruh siswanya merupakan santri dipondok pesantren Al Halim. Semua siswa tinggal di asrama yang telah disediakan. Jumlah siswa untuk setiap kamar asrama mulai dari 674 orang per kamarnya. Karena tinggal diasrama dan dengan jumlah orang perkamarnya yang banyak menyebabkan siswa kurang memperhatikan kebersihan diri. Pada survey awal yang dilakukan oleh mahasiswa Fakultas Keperawatan Unpad dalam mata kuliah Promosi Kesehatan, data yang diambil dari siswa sebanyak 24 orang kebanyakan belum mengetahui tentang personal hygiene. Sebanyak $34 \%$ siswa jarang mencuci tangan sebelum dan sesudah makan dan $29 \%$ tidak mencuci tangannya, 34\% menggunakan sabun batang secara bersamaan, 29\% tidak mengganti pakainnya minimal $1 \mathrm{kali}, 21 \%$ sering pinjam meminjam pakaian dan $70 \%$ lainnya kadang, $16 \%$ siswa masih jarang mandi menggunakan sabun. Menurut penelitian yang dilakukan sebelumnya oleh Prakoso (2015) mengatakan 50\% sebagian santri memliki kebersihan kurang diantaranya, santri yang berganti pakaian dengan temannya $21 \%$, santri yang mandi kurang dari 2 kali sehari $21 \%$ dan santri yang mandi tidak menggunakan sabun aseptic sebanyak $14 \%$. Mengingat bahwa siswa SMK Al Halim seluruhnya merupakan santri Pondok Pesantren Al Halim kedua hasil menunjukan hasil yang relevan yaitu pengetahuan mengenai personal hygiene yang masih kurang.

Kurangnya pengetahuan mengenai perilaku hidup bersih dan sehat tersebut khususnya kebiasaan personal hygiene dapat berdampak terhadap kesehatan siswa Al Halim sendiri. Seperti tidak mencuci tangan menggunakan sabum sebelum dan sesudah makan dapat menjadi penyebab penyakit diare, infeksi saluran pernapasan atas, infeksi cacing, infeksi mata dan infeksi kulit. Karena sabun memiliki zat antibakteri triclosan yang dapat meminimalisir masuknya bakteri ke tubuh melalui makanan. Penggunaan sabun mandi batang secara bersama-sama juga dapat menjadi perantara dalam penyebaran penyakit. Selain penggunaan sabun sering pinjam meminjam pakaian juga dapat menyebabkan penularan penyakit kulit, hepatitis, flu, dan impetigo. Jika salah satu pengguna pakaian mengidap suatu penyakit maka virus maupun bakteri yang dikeluarkan melalui keringat itu akan menempel di baju yang kemudian bisa berpindah keorang yang meminjam baju selanjutnya. Menurut kesiswaan SMK Al Halim sudah sering mendapatkan pendidikan kesehatan dari puskesmas. Tetapi jika melihat dari hasil survey awal tersebut masih menujukan bahwa siswa SMK Al Halim belum memiliki pengetahuan mengenai perilaku personal hygiene yang baik sehingga diperlukan kegiatan pendidikan kesehatan mengenai hal tersebut. Berdasarkan permasalahan terebut diatas maka kami tertarik untuk melakukan kegiatan pengabdian tentang peningkatan pengetahuan siswa dalam pelaksanaan personal hygiene di SMK Al Halim Garut. 


\section{Tujuan Pengabdian}

Tujuan kegiatan pengabdian ini adalah untuk meningkatkan pengetahuan dan pelaksanaan akan pentingnya praktik personal hygiene bagi para siswa di SMK Al Halim Garut. Sedangkan tujuan khusus adalah siswa dapat melakukan cuci tangan dengan enam langkah sebelum dan sesudah makan dengan baik dan benar; menggunakan sabun setiap mandi dan mengganti pakaian setiap hari minimal satu kali.

\section{Manfaat Pengabdian}

Manfaat yang ingin dicapai dalam kegiatan ini adalah diterapkannya pelaksanaan personal hygiene pada siswa SMK Al Halim, sehingga siswa memiliki perilaku hidup bersih dan sehat serta tinggal di lingkungan yang nyaman yang pada akhirnya akan berdampak positif pada prestasi belajar siswa.

\section{Kajian Pustaka}

Kebiasaan hidup sehat merupakan sebuah perilaku. Perilaku sangat mempengaruhi status kesehatan seseorang. Menurut Skiner, perilaku kesehatan adalah suatu respon seseorang (organisme) terhadap stimulus atau objek yang berkaitan dengan sakit dan penyakit, sistem pelayanan kesehatan, makanan dan minuman serta lingkungan Skiner (Notoatmodjo, 2019). Merujuk dari pengertian tersebut perilaku kesehatan di klasifikasikan menjadi: perilaku pemeliharaan kesehatan, perilaku pencarian pengobatan dan perilaku kesehatan lingkungan. Perilaku dapat diukur dengan cara mengamati kegiatan yang dilakukan responden atau dengan menanyakan kegiatan yang sudah dilakukan. Perilaku akan tebentuk apabila dilengkapi dengan faktor predisposisi seperti pengetahuan, sikap, keyakinan, kepercayaan, nilai-nilai. Faktor pemungkin antara lain sarana dan prasarana atau fasilitas dan faktor lainnya adalah faktor penguat yang mendorong atau memperkuat terjadinya perilaku (Notoatmodjo, 2014).

Personal hygiene berasal dari bahasa Yunani yaitu personal berarti perorangan dan hygiene berarti sehat. Personal hygiene adalah cara perawatan diri seseorang untuk memelihara kesehatannya (Aris, 2019). Dari bahasa tersebut dapat dikatakan bahwa personal hygiene adalah ilmu kesehatan tentang perawatan diri seperti mandi, kecantikan dan kebersihan umum. Personal Hygiene mencakup perawatan kulit, rambut, kuku, gigi, rongga hidung dan mulut, mata telinga, dan daerah genital. Personal hygiene bertujuan untuk mencapai kebersihan tubuh; meliputi membasuh, mandi, merawat rambut, kuku, gigi, dan gusi disamping membersihkan daerah genital (Purba, 2013).

Kegiatan personal hygiene yang paling sering diabaikan adalah cuci tangan. Mencuci tangan dengan air bersih dan sabun akan banyak menguragi jumlah mikroorganisme dari kulit dan tangan (Anggraeni 2016). Mencuci tangan menurut Depkes RI dilakukan setelah menggunakan jamban, sebelum memasak, makan, setelah memegang hewan dan setelah makan (Hermawan, 2019). Langkah-langkah cuci 
tangan rutin adalah pertama adalah membasahi tangan dengan air mengalir, kemudian pakai sabun dan gosok bagian tangan dan jari. Langkah berikutnya membilas dengan air bersih kemudian keringkan tangan dengan lap/handuk. Bila handuk tidak tersedia, keringkan dengan udara (Denta, 2018).

\section{Metode}

\section{Tahap Persiapan}

Sebelum melaksanakan kegiatan pengabdian tim melakukan diskusi untuk menyelesaikan permasalahan yang terjadi. Upaya untuk menyelesaikan permasalahan tersebut adalah melakukan pendidikan kesehatan. Langkah pertama untuk melakukan pendidikan kesehatan adalah melakukan pendekatan sosial, diantaranya adalah:

a) Koordinasi dengan pimpinan sekolah untuk menyampaikan hasil survey awal dan mendiskusikan rencana kegiatan pendidikan kesehatan kepada siswa SMK Al Halim.

b) Koordinasi dengan pimpinan puskesmas sebagai penanggung jawab masalah kesehatan di sekolah tempat dilakukan pendidikan kesehatan.

c) Mempersiapkan perijinan kegiatan pendidikan kesehatan.

d) Koordinasi tim pengabdian.

\section{Tahap Pelaksanaan}

Pelaksanaan pendidikan kesehatan diawali dengan breefing anggota tim, pemasangan banner dan persiapan kelengkapan pendidikan kesehatan. Setelah semua siap kegiatan dimulai registrasi bagi siswa yang ingin menghadiri pendidikan kesehatan di SMK Al Halim Garut. Sebelum dilakukan pendidikan kesehatan dilakukan pre-test. Pendidikan kesehatan dilakukan dengan metode cramah, diskusi dan demontrasi. Media yang digunakan proyektor, spanduk dan banner. Materi pendidikan kesehatan adalah tentang gerakan menjaga kebersihan diri. Untuk evaluasi kegiatan, setelah dilakukan pendidikan kesehatan dilakukan post-test.

\section{Hasil dan Pembahasan}

Kegiatan diselenggarakan pada hari Kamis, 21 November 2019 pukul 12.00-16.00 WIB di Aula SMK Al-Halim Garut. Tim melakukan breefing pemasangan banner, membersihkan tempat dan menyiapkan alat logistic. Hal ini ditujukan agar siswa mengetahui maksud dari acara ini. Pemasangan banner ini juga bertujuan agar siswa selalu mengingat apa yang sudah diberikan oleh tim sehingga akan bermanfaat untuk jangka panjang. Tim juga menyediakan bingkisan/souvenir untuk memberikan motivasi kepada siswa untuk ikut berpartisipasi dalam kegiatan. Jumlah siswa yang mengikuti kegiatan awalnya 95 orang dan pada saat pelaksanaan menjadi 155 orang.

Kegiatan ini dimulai dengan pendaftaran peserta bagi siswa yang akan mengikuti Pendidikan Kesehatan. Setelah semua siswa masuk di aula kemudian dilakukan pretest selama 20 menit. Pre-test diikuti hanya oleh 94 siswa yang masuk diawal. Rata rata 
nilai pre-test yaitu sebesar 54,15. Sebelum memberikan materi dilakukan dulu apersepsi tentang personal hygiene dengan menanyakan sejauh mana siswa mengetahui tentang Persona Hygiene. Apakah siswa mengetahui pentingnya menjaga kebersihan diri, dan apa saja langkah-langkah mencuci tangan dengan benar. Dari semua jawaban siswa, siswa cukup mengenal pentingnya personal hygiene, namun siswa masih belum paham mengenai langkah-langkah mencuci tangan dengan benar dan apa saja dampak dari tidak menjaga kebersihan diri yang berdampak bahaya bagi kesehatan.

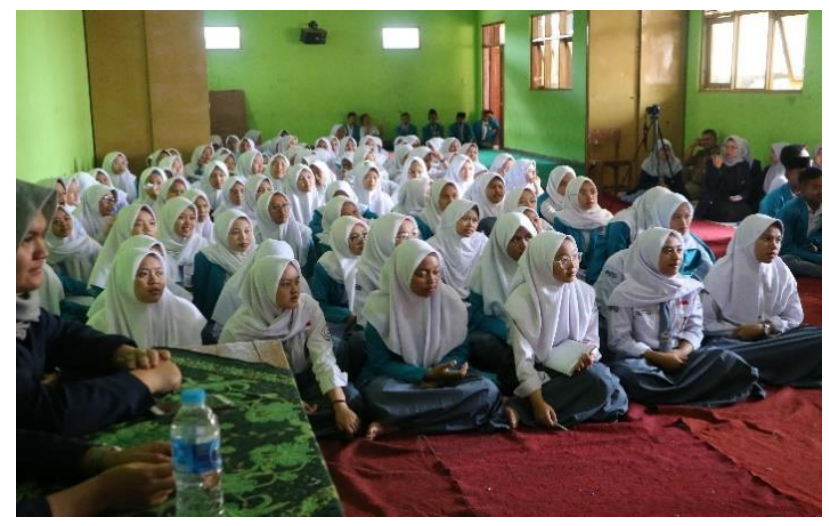

Gambar 1 (a)

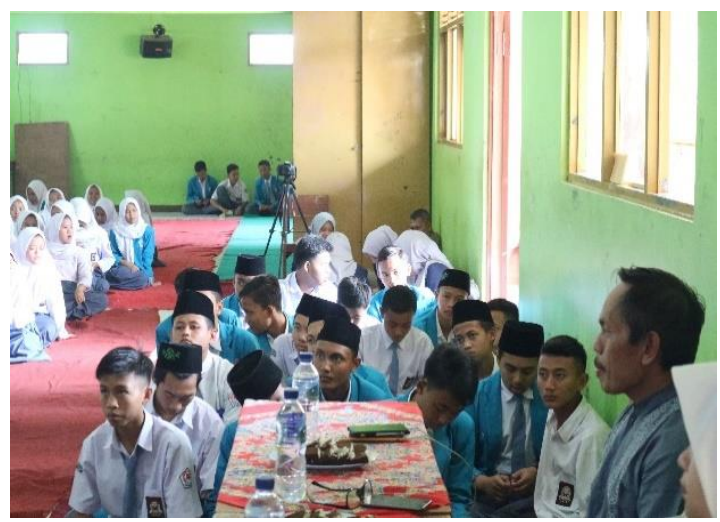

Gambar $1(b)$

Gambar 1(a) dan 1 (b) Peserta kegiatan

Pendidikan kesehatan yang digunakan dengan menggunakan media Persentation Power Point (PPT), pemutaran video dan demonstasi yang sudah tim siapkan. Materi yang disampaikan ialah mengenai Personal Hygiene. Pemberian materi berjalan dengan lancar dan peserta sangat fokus memerhatikan apa yang sedang disampaikan. Pemberian materi ini menggunakan metode ceramah dan tanya jawab dan selalu memberi kesempatan pada siswa untuk menyampaikan pendapatnya. Setelah PPT selesai ditampilkan, pemateri langsung menampilkan video yang sudah disiapkan. Video yang ditayangkan pun harus diikuti oleh semua siswa. Setelah materi selesai disampaikan, dilanjut dengan demonstrasi tentang 6 langkah mencuci tangan dengan benar. Sesi demonstasi ini bertujuan agar siswa dapat mempraktikan pada kegiatan sehari-hari dengan benar. Pada sesi ini siswa sangan antusias dan ada beberapa reward atau doorprize bagi siswa yang dapat mempraktikannya dengan benar di depan temantemannya. Selanjutnya sesi tanya jawab pertanyaan ini diajukan dari siswa yang mempunyai pertanyaan mengenai Personal Hygine. 


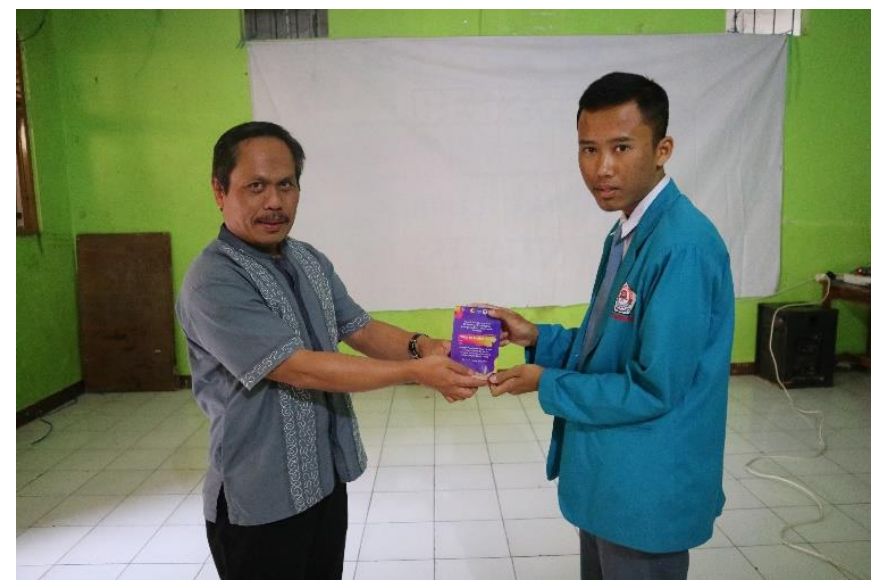

Gambar 2. Pemberian doorprize kepada peserta kegiatan

Tim menyediakan doorprize untuk siswa yang berpartisipasi dan mengemukakan pendapatnya. Pertanyaan diajukan oleh 6 siswa dan selanjutnya pemateri menjawab pertanyaan yang diajukan oleh siswa. Doorprize diberikan oleh pemateri. Setelah sesi doorprize, dilakukanlah sesi terakhir dari kegiatan pendidikan kesehatan ini yaitu sesi penutup. Sebelum melakukan penutupan kami membagikan kuesioner pos-test dengan soal yang sama kepada 94 siswa yang telah mengisi kuesioner pre-test sebelumnya. Pos-test dilakukan untuk mengetahui sejauh mana perubahan pengetahuan siswa mengenai pentingnya Personal Hygiene setelah diadakannya pendidikan kesehatan. Karena semangat siswa yang sangat baik dalam mengikuti pendidikan kesehatan ini ternyata ada peningkatan rata rata nilai post-test yaitu menjadi 74,77 .

Hasil pengabdian ini menunjukan bahwa pengetahuan siswa tentang personal hygiene awalnya diperoleh rata-rata nilai 54,15 . Setelah dilakukan pendidikan kesehatan diperoleh rata-rata nilai 74,77 . Terdapat peningkatan pengetahuan siswa setelah dilakukan pendidikan kesehatan. Sehingga disimpulkan terdapat perbedaan rata-rata nilai pre-test dan post-test untuk pengetahuan siswa tentang kebersihan diri. Hal ini sejalan dengan penelitian yang dilakukan oleh (Fatmawati, 2018) tentang Pengaruh Pendidikan Kesehatan Terhadap Pengetahuan Tentang Personal Hygiene Pada Anak Usia Sekolah Di SDN 206/IV Kota Jambi, menunjukkan ada pengaruh yang signifikan antara pengetahuan responden sebelum dengan setelah diberikan pendidikan kesehatan.

Penelitian lain yang memperkuat hasil pengabdian ini adalah penelitian (Hidayati, Salawati, \& Istiana, 2013) tentang pengaruh pendidikan kesehatan melalui metode ceramah dan demonstrasi dalam meningkatkan pengetahuan tentang kanker payudara dan keterampilan praktik sadari (Studi pada Siswi SMA Futuhiyyah Mranggen Kabupaten Demak). Berdasarkan hasil penelitian tersebut, pendidikan kesehatan melalui metode ceramah dan demonstrasi keterampilan praktik 
berpengaruh terhadap pengetahuan dan keterampilan. Menurut Notoatmodjo (2014) pendidikan kesehatan akan menimbulkan efek yang baik apabila proses penyampaian pendidikan kesehatan menggunakan media-media yang baik. Media yang digunakan pada pendidikan kesehatan ini adalah ceramah, power point dan leaflet. Pendidikan kesehatan dengan media ceramah, power point dan leaflet mampu meningkatkan pengetahuan. Memperhatikan hal tersebut adanya peningkatan pengetahuan siswa dalam kegiatan pengabdian ini dikarenakan penggunaan media dan metode yang tepat. Karena hal tersebut akan menggiring siswa lebih fokus terhadap materi yang disampaikan. Pendidikan kesehatan yang dilakukan dapat meningkatkan pengetahuan dan keterampilan apabila menggunakan metoda ceramah dan demonstrasi serta media power point dan leaflet, sehingga dapat menjadi salah satu metode pilihan umtuk pendidikan kesehatan.

Dalam kegiatan pendidikan kesehatan kepada siswa perlu dipikirkan agar siswa memiliki konsentrasi yang kuat. Hal tersebut akan memudahkan siswa menerima materi. Agar siswa memiliki konsentrasi yang baik diperlukan media dan metode yang menarik dan mudah disimak oleh panca indra. Penggunaan panca indra yang maksimal akan menentukan keberhasilan pendidikan kesehatan. Penelitian (Asih, Sunarno, \& Marettina, 2012) menyatakan bahwa 100\% responden mengalami peningkatkan pengetahuan jika dalam proses penyampaian informasi melibatkan indera penglihatan dan pendengaran. Menurut (Notoatmodjo, 2010), bahwa salah satu upaya untuk meningkatkan pengetahuan adalah dengan pendidikan kesehatan. Pendidikan kesehatan yang lakukan selama 110 menit dengan menggunakan metoda ceramah, bahasa-bahasa yang mudah dimengerti sehingga mampu dipahami oleh siswa. Intervensi yang dilakukan berhasil meningkatkan pengetahuan dan keterampilan menggunakan metoda ceramah dengan media power point dan leaflet (Wijayanti, Isnani, \& Kesuma, 2016).

\section{Simpulan dan Rekomendasi}

Pendidikan kesehatan merupakan kegiatan yang efektif dan efisien sebagai upaya untuk meningkatkan pengetahuan siswa tentang personal hygiene. Dalam pengabdian ini ada peningkatan rata-rata nilai pengetahuan siswa SMK Al Halim sebelum dan sesudah dilaksanakan pendidikan kesehatan. Pengetahuan siswa tentang personal hygiene yang sudah baik perlu dibina lebih lanjut oleh sekolah maupun puskesmas. Sebaiknya sekolah membuat program tindak lanjut untuk menilai perilaku siswa dalam kebersihan dirinya.

\section{Penghargaan}

Ucapan terimakasih kepada Rektor Universitas Pajajaran, Dekan Fakultas Keperawatan Universitas Pajajaran, Pimpinan SMK Al Halim Garut, Pimpinan Puskesmas Tarogong-Garut, segenap mahasiswa promkes angkatan 2018 dan pihakpihak yang sudah membantu kegiatan pengabdian masyarakat. Semoga bantuannya menjadi amal baik dan medapat balasan dari Allah SWT. Aamiin. 


\section{Daftar Pustaka}

Anggraeni, E. S. (2016). Perbedaan Pedidikan Kesehatan Metode Demonstrasi Secara Langsung Dengan Audio Visual Tentang Cuci Tangan Terhadap Praktek Dan Perilaku Cuci Tangan Pada Anak Usia Pra Sekolah. Universitas Muhammadiyah Purwokerto. Universitas Muhammadiyah Purwokerto.

Aris, I. (2019). Pengetahuan Dan Sikap Lansia Tentang Personal Hygiene Di Panti Jompo Welas Asih Kecamatan Singaparna Kabupaten Tasikmalaya. Fakultas Ilmu Kesehatan.

Asih, S. H. M., Sunarno, R. D., \& Marettina, N. (2012). Pengaruh pendidikan kesehatan tentang penatalaksanaan ispa terhadap pengetahuan dan keterampilan ibu merawat balita ispa di rumah. Karya Ilmiah.

Denta, S. P. (2018). Praktik Cuci Tangan Enam Langkah Menggunakan Sabun Dan Air Mengalir Pada siswa sekolah dasar Kelas 1 di SD N 1 Ngestiharjo Tanungsari Gunungkidul. Stikes Panti Rapih Yogyakarta.

Dinas Kesehatan Kabupaten Garut. (2017). Profil Kesehatan Kabupaten Garut 2016.

Fatmawati, T. Y. (2018). Pengaruh Pendidikan Kesehatan Terhadap Pengetahuan Tentang Personal Hygiene Pada Anak Usia Sekolah Di SDN 206/Iv Kota Jambi. Jurnal Akademika Baiturrahim Jambi, 7(1), 10-16.

Hermawan, M. M. F. (2019). Gambaran Permasalahan Kesehatan Integumen Dan Perilaku Personal Hygiene Santri Di Pondok Pesantren X. University of Muhammadiyah Malang.

Hidayati, A., Salawati, T., \& Istiana, S. (2013). Pengaruh pendidikan kesehatan melalui metode ceramah dan demonstrasi dalam meningkatkan pengetahuan tentang kanker payudara dan ketrampilan praktik sadari (Studi pada Siswi SMA Futuhiyyah Mranggen Kabupaten Demak). Jurnal Kebidanan, 1(1), 1-8.

Irnawati, I., \& Kamalah, A. D. (2020). Pendidikan Kesehatan dan Pengobatan Sebagai Preventif dan Kuratif Menuju Masyarakat Sehat di Desa Pedawang Kabupaten Pekalongan. Proceeding of The URECOL, 1-4.

Juliansyah, E., \& Minartami, L. A. (2017). Jenis Kelamin, Personal Hygiene, dan Sanitasi Lingkungan dengan Kejadian Penyakit Scabies Pada Santri di Pondok Pesantren Darul Ma'arif Kabupaten Sintang. Jumantik, 4(1).

Notoatmodjo, S. (2010). Pengantar Pendidikan Kesehatan dan Ilmu Perilaku. Yogyakarta: Andi Offset.

Notoatmodjo, S. (2014). Promosi Kesehatan dan Perilkau Kesehatan. Jakarta: Rineka Cipta.

Notoatmodjo, S. (2019). Promosi kesehatan dan ilmu perilaku.

Prakoso, D. Y. (2015). Pengaruh Pendidikan Kesehatan Tentang Personal Hygiene 
Dengan Metode Ceramah Dan Media Audiovisual Terhadap Pengetahuan Dan Sikap Remaja Putri Dalam Mencegah Keputihan Di SMK Bakti Purwokerto. Universitas Muhammadiyah Purwokerto.

Proverawati, A., \& Rahmawati, E. (2012). Perilaku hidup bersih dan sehat (PHBS). Yogyakarta: Nuha Medika.

Purba, C. V. G. (2013). Pengaruh Personal Hygiene dan Sanitasi Lingkungan terhadap Kejadian Skabies pada Anak Usia Sekolah di Kecamatan Lubuk Pakam Kabupaten Deli Serdang Tahun 2013.

Sulistyowati, D., \& Handayani, F. (2012). Peran Perawat Dalam Pelaksanaan Personal Hygiene Menurut Persepsi Pasien Imobilisasi Fisik. Jurnal Keperawatan Diponegoro, 1(1), 169-174.

Wijayanti, T., Isnani, T., \& Kesuma, A. P. (2016). Pengaruh penyuluhan (ceramah dengan power point) terhadap pengetahuan tentang leptospirosis di Kecamatan Tembalang, Kota Semarang Jawa Tengah. Balaba: Jurnal Litbang Pengendalian Penyakit Bersumber Binatang Banjarnegara, 12(1), 39-46. 